\title{
The Geometry and Structural Analysis of the Gold Deposits of Chirano Mine*
}

\author{
${ }^{1}$ K. Ackun-Wood, ${ }^{2}$ J.S.Y. Kuma and ${ }^{2}$ J. A. Yendaw \\ ${ }^{1}$ Chirano Gold Mines Limited, Kinross Company, Chirano, Ghana \\ ${ }^{2}$ University of Mines and Technology, P.O. Box 237, Tarkwa, Ghana
}

Ackun-Wood, K., Kuma, J.S.Y. and Yendaw, J. A. (2016) "The Geometry and Structural Analysis of the Gold Deposits of Chirano Mine", Ghana Mining Journal, Vol. 16, No. 2, pp. 10 - 19.

\begin{abstract}
The Chirano Mine gold deposit is a typical example of a structurally controlled deposit developed along the Kumasi Basin and the Sefwi Belt margin structure. The area has undergone various regimes of structural deformations. Consequently, all the Chirano deposits are intimately associated with shears and faults along a single continuous structural corridor known as the Chirano Shear Zone (CSZ). The CSZ geometry has been categorised into three major zones namely: (i) Laminated veins in shears, (ii) Breccia and (iii) Ductile to brittle ductile zones. The shear veins trend NE-SW and N-S, are laminated and occur in the sheared fabric close to the footwall. Penetrative foliated zones varying from a few centimeters to several meters constitute the ductile to brittle-ductile structures. Gold grades are much higher within this zone. Analysis of cataclasis intensity recorded in drill core confirms a semi brittle form of deformation within the mineralised domain. The CSZ has different orientations in dip and strike from the south of the mining lease to the north. The subtle changes in orientation are deposit dependent. The structure has a sinuous shape and tends to pinch and swell. The current geometry and the distribution of stratigraphy and orebodies at Chirano is a manifestation of the complex interplay of magmatic and hydrothermal events in the area.
\end{abstract}

Keywords: Ductile, Brittle-Ductile, Breccia, Chirano Shear Zone, Chirano Lode Horizon

\section{Introduction}

Gold deposits at Chirano Gold Mines Limited (CGML) situated on the Sefwi Gold Belt in south western Ghana, occur along fractured, brecciated and ductile to brittle-ductile parts of shear zones. The mine is about $90 \mathrm{~km}$ south-west of Kumasi, on latitude $6^{\circ} 36^{\prime} \mathrm{N}$ and longitude $2^{\circ} 17^{\prime} \mathrm{W}$ (Fig. 1). A fault between the Sefwi Belt and the Tarkwaian sediments locally known as the Chirano Shear Zone (CSZ) is a splay of the Bibiani Shear zone (Anon., 2009). The CGML has nine deposits evenly spaced over a ten kilometer strike line in a mineralised zone called the Chirano Lode Horizon (CLH). According to Anon. (2009), the CLH is characterised by foliation, veining and brecciation within 200 meters west of the CSZ and hosted by fractured and altered mafic volcanic rocks and granites. The deposits seem to be structurally controlled; however, there is no current knowledge of deposit scale structural control styles as the concession area appears to have undergone various regimes of structural deformation.

In this paper we characterise and analyse the geometry and structural footprints of the Chirano gold deposits. The study presents field based structural relationships of the individual deposits.

\subsection{Regional Geological Setting}

The Chirano deposits lie within the Paleoproterozoic Birimian rocks of south-western Ghana on the West Africa Craton. The West African Craton consists of an Archean core, referred to as the Man Shield and a Paleoproterozoic domain with relics of Archean basement (Milési et al., 1989). The Man Shield dominates the southern part of the West African Craton. Its western-most part is predominantly of Archean age $(\sim 3.0-2.5 \mathrm{Ga})$ while the eastern part comprises the Birimian rocks of early Proterozoic age (Leube et al., 1990). The Birimian represents part of a major Paleoproterozoic juvenile crustforming event; the Eburnean orogeny (Davis et al., 1994). The Birimian supracrust of the Guinea Rise resembles Archean greenstones except for the absence of Komatiitic volcanic rocks (Condie, 1989).

According to Kesse (1985), the Birimian terrains in Ghana consist of five northeast-trending volcanic belts that stretch for $\sim 500 \mathrm{~km}$ in a NE-SW direction and separated from one another by metasedimentary basins of up to $\sim 200 \mathrm{~km}$ wide (Fig. 1). The volcanic belts consist mostly of metamorphosed volcanic rocks of tholeiitic to calcalkaline composition. The metasedimentary basins contain metamorphosed volcaniclastics, wackes and argillitic sedimentary rocks. Available field 
evidence suggests that the volcanic and sedimentary rocks are lateral equivalents (Leube et al., 1990).

Coarse clastic sedimentary rocks of fluvio-deltaic origin referred to as the Tarkwaian Group of rocks also occur in areas underlain by the Birimian Supracrustals. Age dating suggests that the Birimian and Tarkwaian sedimentation broadly overlap in the period 2140 to 2100 Ma. However, clasts of Birimian rocks within the Tarkwaian suggest that locally the Tarkwaian is younger (Pigois et al., 2003).

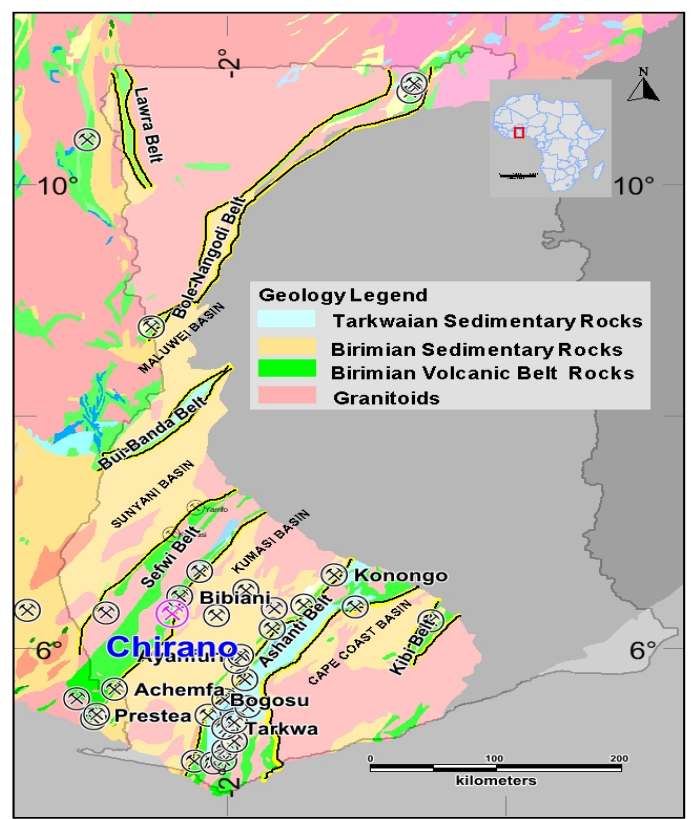

Fig.1 Regional Geological Map of Ghana illustrating the Volcanic Belts and Major Known Gold Deposits (modified after Allibone et al., 2002)

The Birimian rocks are isoclinally folded and form an overthrust fold with a NE-SW trend and near vertical axial planes dipping $65^{\circ}$ to $90^{\circ}$ (Leube et $a l ., 1990)$. The truncation of folds by thrusts along the northwest margin of the Ashanti Belt indicates that folding occurred prior to thrusting. Gravity profiles across the Ashanti Belt supports a series of deep-seated thrusts and associated regional scale folds (Barritt and Kuma, 1998).

Two types of deformation recognised in the Birimian rocks are low and high strain deformations (Ledru et al., 1988; Eisenlohr, 1992; Eisenlohr and Hirdes, 1992). The low strain deformation resulted in development of $\mathrm{NE}$ trending sub-vertical $\left(\mathrm{S}_{1}\right)$ foliations whilst rocks of high strain deformation occur mostly along the northwestern margins of the volcanic belts near the contact with Tarkwaian rocks and is characterised by a more intense penetrative NE trending $\left(\mathrm{S}_{2}\right)$ foliation that is represented by development of elongated recrystallised quartz grains and well- aligned phyllosilicates. Milesi et al. (1989) and Milesi et al. (1991) refer to the two types of deformation as compressive D1 and D2 deformations respectively and associated them with the Eburnean 1 and 2 orogenic events.

The Birimian-Tarkwaian contact is strongly tectonised with repetition of stratigraphy; overturned bedding and stretched lineation indicating that the Birimian volcanic rocks were thrust obliquely onto the Tarkwaian rocks (Milesi et al., 1989; Dzigbodi-Adjimah and Asamoah, 2004). The Birimian is characterised by the emplacement of large granitoid plutons that are associated with the Eburnean orogeny that took place between $2184 \pm 60$ and $2073 \pm 29 \mathrm{Ma}$. Three types of granitoids of distinct geochronological and geochemical suites are known to intrude the Birimian Supergroup and Tarkwaian Group. Eisenlohr and Hirdes, (1992) refers to them as the Cape Coast (G1), Dixcove (G2) and Bongo (G3) granitoids Leube et al. (1990) and Eisenlohr and Hirdes (1992) provide the following distinguishing characteristics of the different granitoids:

(i) The Cape Coast or basin-type granitoids $(2116 \pm 2.2 \mathrm{Ma})$ are large, syntectonic, foliated granitoid batholiths that typically intrude the Birimian sedimentary strata. Typical lithologies include tonalites, trondhjemites, granodiorites, adamellites and granites. These granitoids have extensive contact metamorphic aureoles with mineral assemblages that indicate pressures of at least $4 \mathrm{~kb}$ and temperatures around $500{ }^{\circ} \mathrm{C}$.

(ii) The Dixcove or belt-type granitoids (2178 $\pm 2.3 \mathrm{Ma}$ ) are small, unfoliated plutonic bodies that intrude Birimian volcanic belts. This suite consists of quartz-diorite, tonalite, trondhjemite, granodiorite, adamellite, and to a lesser degree, granite.

(iii) The Bongo-type granitoids intrude Tarkwaian sediments in the Bole-Navrongo Belt, and show unusually high Kconcentrations. They are post-tectonic in origin (evidenced by lack of foliations) and are petrographically characterised by pink phenocrysts of alkali feldspar.

\subsection{Geology of the Chirano Gold District}

The Chirano gold district straddles the Sefwi Volcanic Belt to the west and the sedimentary Kumasi Basin to the east. A thin sliver of younger Tarkwaian epiclastic sediments occurs along the belt and basin contact at Chirano. A fault between the Sefwi belt and the Tarkwaian sediments locally known as the CSZ is a splay of the Bibiani Shear 
Zone (the fault between the Tarkwaian and the Birimian sedimentary rocks, Fig. 2). The Chirano deposits are proximal to the CSZ and lie directly on the shear at the southernmost deposit known as Akwaaba. The deposits occur at regular intervals along a $10 \mathrm{~km}$ long mineralised zone called the $\mathrm{CLH}$ which is characterised by foliation, veining and brecciation within 200 meters west of the CSZ and hosted by fractured and altered mafic volcanic rocks and granites. The CLH seems to be a splay of the CSZ.

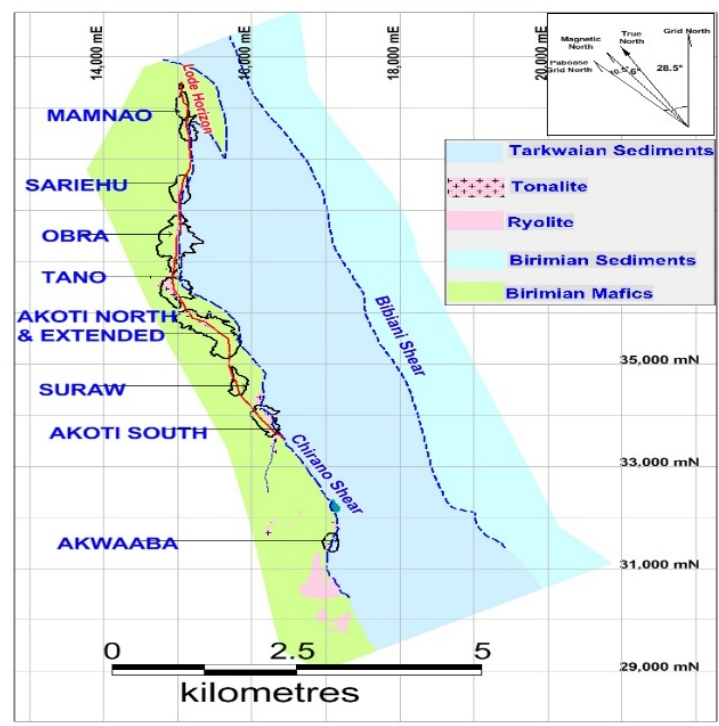

Fig 2 An Updated Local Geology of the Chirano District

Alteration assemblages found in Chirano include: carbonate alteration, sulphidation, albitisation and hematite dusting. Gold mineralisation of the Chirano deposits is associated with ankeritesericite-albite-silica-hematie-pyrite assemblage (Woolford, 2007). The alteration patterns are however host rock dependent. The mafic units generally are more ankerite-rich whereas the quartz bearing units have more albite. Alteration within the mineralised zones is quite strong and pervasive. The Tarkwaian sediments are strongly quartzalbite-ankerite-sericite altered in close proximity to the Chirano shear (Woolford, 2007).

\subsection{Chirano District Scale Deformation}

Two deformation events have been recorded in the Chirano District with two others being speculative.

The first deformation event (Di), though speculative, involved folding and thrusting. The second phase of deformation (Dii), evidenced in the field by bedding-cleavage relationships within the Tarkwaian sedimentary rocks, comprises open, gently N-S plunging folds. The third phase, (Diii) is observed as steeply-dipping, northwest striking fault zones. The mineralised CSZ formed during the Diii event, and is intruded by tonalite and later by hydrothermal fluids during which gold was deposited. A speculative fourth phase of deformation (Div), involved NE trending faults that cut across earlier (Diii) structures like the Chirano shear (Anon, 2008).

\section{Resources and Methods Used}

In order to accurately delineate the major structures at Chirano, the approach adopted integrated historical geological and geophysical datasets comprising electrical surveys obtained in 2002 and from 2006 - 2010, deposit scale pit maps, trench data and drill hole data from both percussion and diamond core drilling programmes. Leapfrog software was then used to model the structures and related fault traces.

\section{Results and Discussion}

\subsection{Results}

Six prominent deposits were identified, namely:

(i) Sariehu Deposit;

(ii) Obra Deposit;

(iii) Tano Deposit;

(iv) Paboase Deposit;

(v) Akoti North-Akoti Extended Deposit; and

(vi) Akwaaba Deposit.

\subsubsection{Sariehu Deposit}

The CLH as seen in the Sariehu pit (Fig. 3) is a N-S trending with west dipping strike-slip fault that seems to have been active during mineralisation. The orientation of the CLH changes to NE-SW at the northern half of the deposit. On a deposit scale, the CLH subtly bends to the right which is a dextral jog by definition and might be as a result of strikeslip faulting.

A fault with $85^{\circ}$ dip and $040^{\circ}$ strike appears to intersect, but not displace, the mineralised CLH around 38,450 $\mathrm{N}$ mine grid (Allibone et al., 2004). The CSZ is in close proximity to the CLH from the southern part of the deposit and swings further to the east from the northern half of the pit (Fig. 4).

The CLH shows extensive quartz veining and abundant pyrite at Sariehu. At least four directions of veining namely N-S, NE-SW, NW-SE and NNW-SSE observed in the pit, are related to mineralisation. The veins generally dip from steep, through moderate to shallow angles and towards the west. The NE-SW veins are parallel to and at high angles to the CSZ. Distinct coarse-grained and laminated vein textures in sheeted veins occur in the hanging wall of the Sariehu pit. These veins are closely spaced where they are in close proximity to the CLH (Fig. 5). 


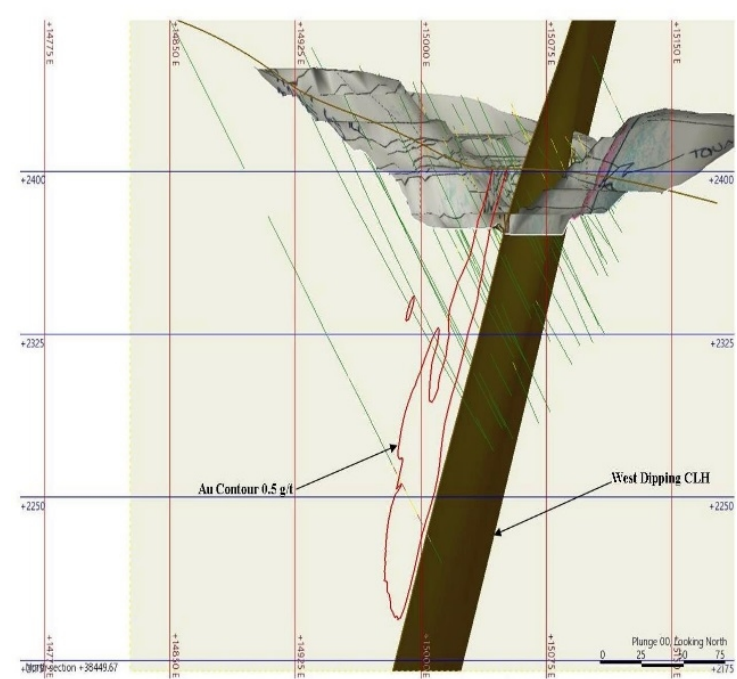

Fig. 3 West Dipping Lode Horizon and Gold Contour as seen in Sariehu

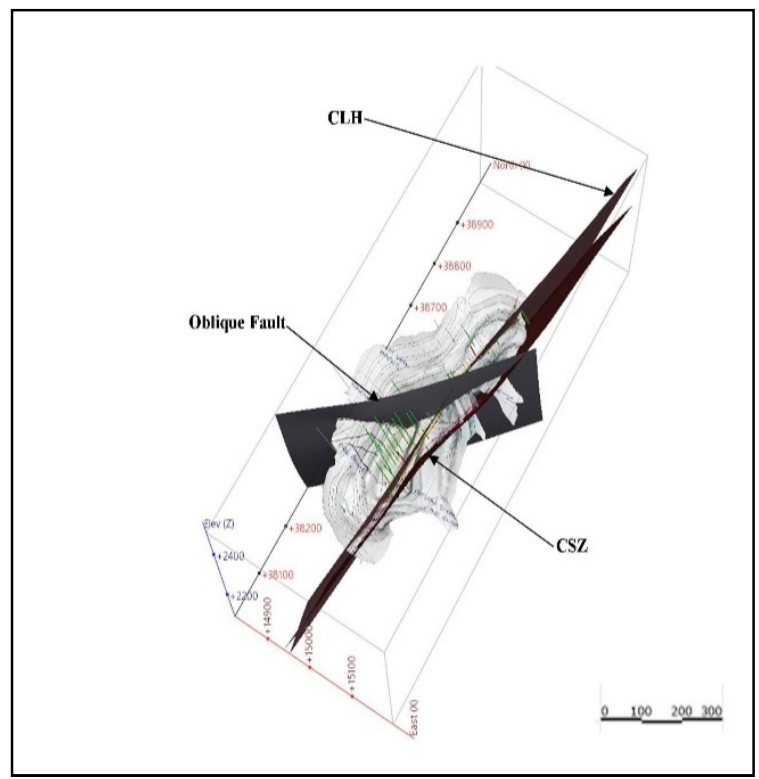

Fig. 4 Aerial view of Sariehu showing the CSZ and the CLH

The N-S and NE-SW veins are sheared and laminated. They occur in a sheared mafic fabric close to the footwall. Within the hanging wall, subvertical extensional veins of vitreous quartz in the middle and carbonate at the edges and with NNWSSE trend form en-echelon arrays oblique and perpendicular to the sheared veins.

An extensive zone of quartz veining and quartz replacement occurs west of the footwall structure.There are at least three phases of quartz veins within the quartz rich zone namely:

(i) Mineralised dark/light grey/white quartz veins with pyrite; (ii) Weakly mineralised to barren white quartz veins with minor pyrite association. These quartz veins seem to be late and

(iii) Milky (glassy clear to slightly purplish coloured quartz vein) late phase quartz vein which marks the footwall of the mineralisation.

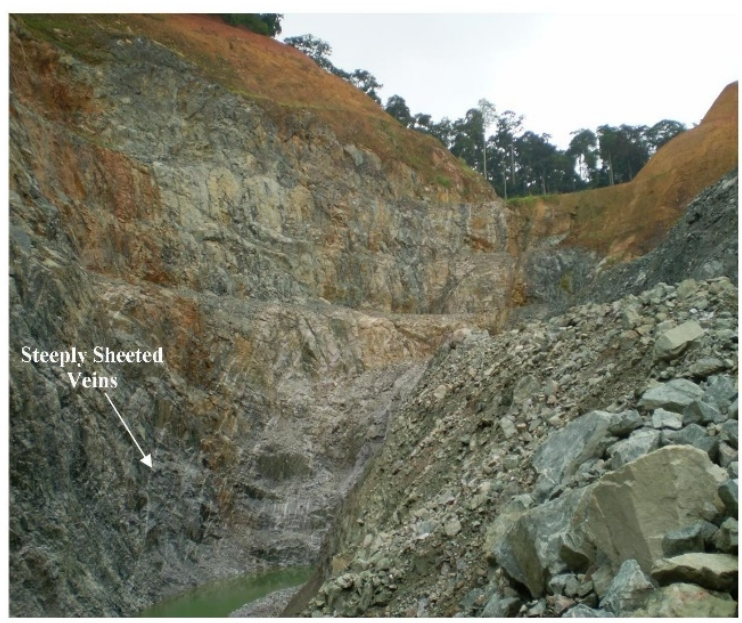

Fig.5 Steeply Sheeted Veins in the Hanging Wall (Sariehu Pit looking NW)

Majority of the veins are between 5 and $20 \mathrm{~cm}$ wide, dip steeply at about $65^{\circ}$ and strike $335^{\circ}$. Pyrite is typically superimposed on the selvedges and appears finer grained in the quartz fill. Early quartz veins that are parallel to foliation contain gold. Possibly syn-deformation and late gold veins are narrow stringers. Thinner, $2-5 \mathrm{~cm}$ wide generally sub-vertical white quartz/carbonate extensional veins cross cut the mineralised veins.

The CSZ at Sariehu has a rather thin zone of shearing with a fault gouge of about $10-15 \mathrm{~cm}$. A conglomerate unit of the Tarkwaian occurs just proximal to the east.

\subsubsection{Obra Deposit}

The two dominant structures, the CLH (locally referred to as the Obra fault) and the CSZ bound the mineralisation in the Obra deposit on the west and east respectively (Fig. 6) and both strike grid north at the southern sector of the pit similar to the regional structure. The Obra fault is characterised by intense shears, foliation and a $10 \mathrm{~m}$ wide mylonitised zone. The fault gouge is about $15 \mathrm{~cm}$ thick and the infill is composed of clay-hematitechlorite-carbonate materials. The mylonitised zone contains sigmoidal shaped shear veins suggesting a brittle-ductile regime of deformation. The degree of intensity of foliation decreases to the west of the Obra fault.

The CSZ occurs in the Obra pit as a contact between highly altered and a mineralised mixture 
of granitoids and a mafic package in addition to altered Tarkwaian sediments. Foliation is mostly within a meter of the structure.

Just north of $37,500 \mathrm{~N}$ mine grid, both shear zones tend to strike grid NE at approximately $030^{\circ}$. The distance between the two shears narrows from about $50 \mathrm{~m}$ to about $20 \mathrm{~m}$ and with a coincident decrease in the width of alteration and mineralisation. The distance between the two shear zones continues to narrow to the north until they eventually merge between Obra and Sariehu to the north.

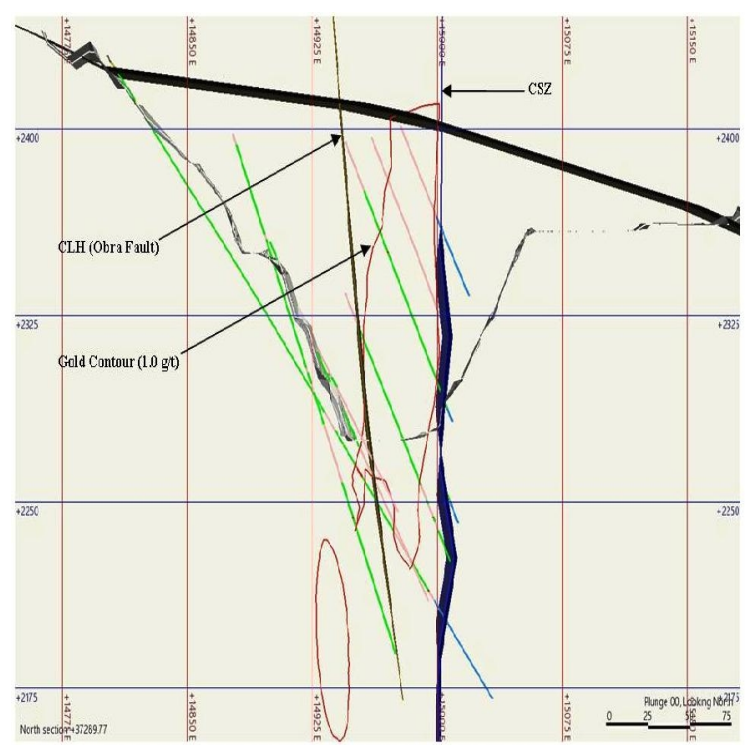

Fig. 6 Sectional View (Looking North) of Bounding Structures in Obra

Mineralisation is hosted within a strongly hydrothermally altered, brecciated and veined package of about $50 \mathrm{~m}$ wide. Evidence of the intensity of cataclasis recorded in drill core confirms semi brittle deformation within the mineralised zone (Fig. 7).

The CSZ seems to deviate towards the southeastern direction at the southern end of the pit at about $15000 \mathrm{E} / 37150 \mathrm{~N}$ (mine grid).

In the Obra pit there is clear evidence of steeplydipping NE-SW and relatively shallow dipping NW-SE trending faults some of which almost certainly pre-date the gold mineralisation in the main hydrothermal breccia body (Anon, 2009). Many of these faults can be observed along the western pit wall and in the southern portion of the eastern pit wall.

\subsubsection{Tano Deposit}

The CLH strikes NW from the southern end of the Tano pit and swings to the right striking N-S. Locally, the CLH is referred to as the Tano fault. It dips steeply at about $83^{\circ}$ to the west and has severe deformation with brecciation. Significant cataclasis recorded on both sides of the lode indicates semibrittle deformation. The Tano fault is associated with a massive quartz vein about a couple of meters wide and parallel to the fault. A mylonite fabric occurs just east of the fault.

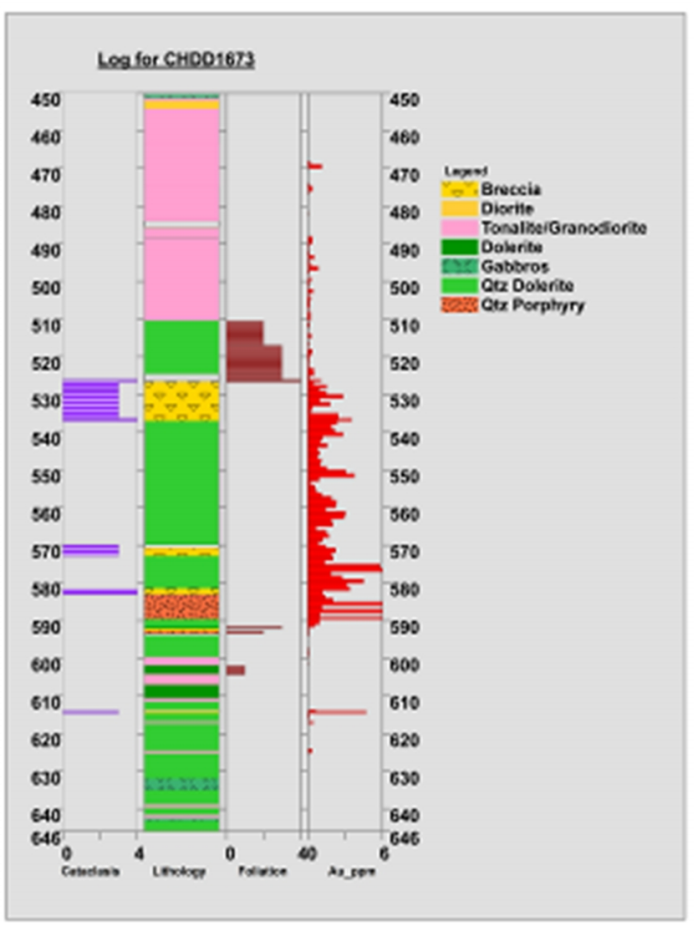

Fig. 7 Graphic Log of CHDD1673 showing Foliation and Cataclasis.

The CSZ manifests itself in Tano on the upper eastern walls of the pit. It strikes N-S and swings to about $45^{\circ}$ and dips approximately $74^{\circ} \mathrm{W}$. It exhibits a zone of intense shearing of up to about $10 \mathrm{~m}$ of foliated Tarkwaian sediments and mafic volcanic rocks to the east and west respectively. Unlike in Obra, the CSZ at Tano does not carry any gold grades.

The Tano fault (Fig. 8), exhibits several generations of fabric development as a consequence of early ductile to late brittle reactivation during progressive compression and deformation along the footwall shear-plane.

Lineation and fault steps on a slickenside surface of the CSZ suggest that the west block moved south and down relative to the east block. Lineation plunge measurements average $20^{\circ}$ with an azimuth of about $173^{\circ}$.

A zone of sheared and partially altered polymictic Tarkwaian conglomerate sits proximal to the CSZ. The Tarkwaian sediments are made of bedded siltstone and arkose. Graded bedding indicates a younging direction to the east. 


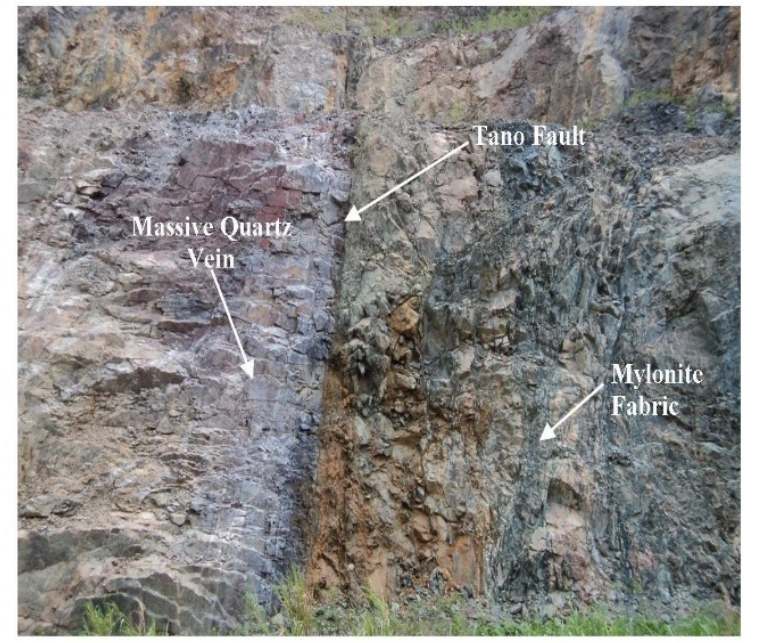

Fig. 8 Image of the Tano Fault (Looking North)

\subsubsection{Paboase Deposit}

The CLH is manifested within the Paboase deposit as a linear structure after a major bend. The strike of the lode extends from Akoti to Tano. There are various structural geometries within the CLH at Paboase (Fig. 9). The structure sequence and morphology hosting the Paboase mineralised zone ranges from ductile to brittle-ductile fabric and shears, to brittle structures including breccia, fault zones and veins. Gold grades are much higher within the brittle-ductile domain (Fig. 10). Adjacent to the brittle-ductile domain is a more brittle domain characterised by faults, brecciated network, and stockwork of veins. A second fault zone which seems to have been reactivated after mineralisation occurs to the east of the CLH. This fault zone is about $1 \mathrm{~m}$ wide with broken ground and fault gouge. An un-mineralised zone of deformation and alteration occurs on the eastern side of this fault.

The Paboase pit is dominated by tonalites and dolerites. According to Allibone et al. (2004), there is a marked increase in the width of the tonalite intrusion that partly hosts the mineralisation suggesting a relationship between the CSZ geometry and the location of more extensive tonalite in the Paboase jog. Stereographic plots of foliations in Paboase drill core indicate that these structures dip steeply to the east.

\subsubsection{Akoti North-Akoti Extended Deposit}

There is a marked kink in both the CLH and the CSZ at Akoti North-Akoti Extended deposit (Fig. 11).At the southern end of the Akoti pit, the CLH strikes N-Sand dips steeply to the west at approximately $80^{\circ}$.

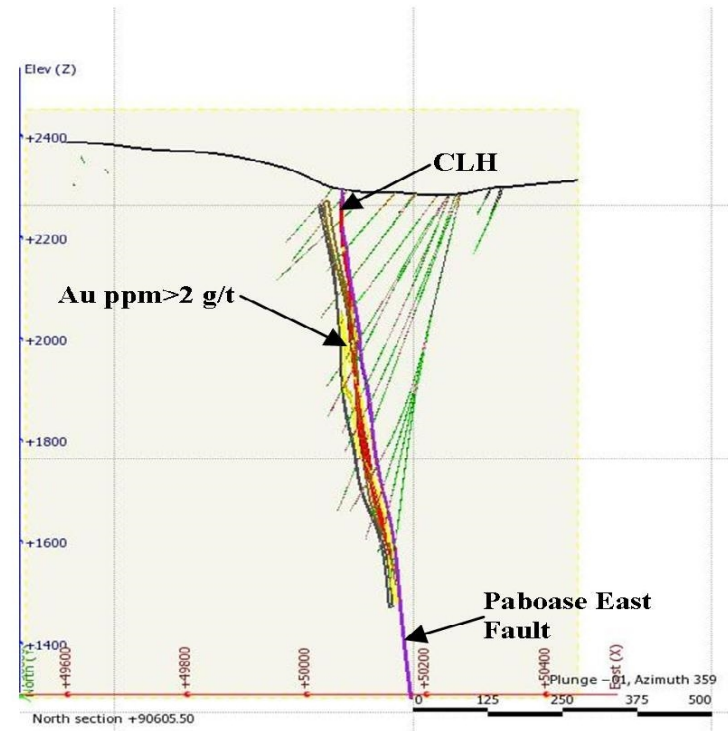

Fig. 9 North Section of Paboase Deposit showing the Various Structural Shapes

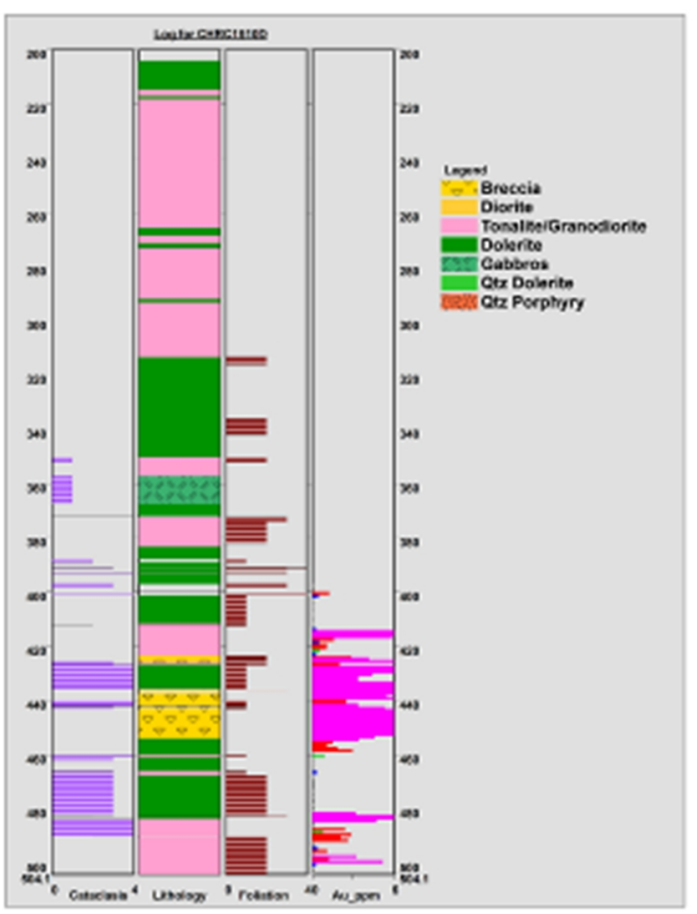

Fig. 10 Graphic Log Plot of CHRC1510D illustrating Structural Matrix

However, at the northern end of the pit and extended to Paboase, the orientation changes to NW-SE strike with a dip of about $82^{\circ}$ to the east.

A major planar fault at Akoti pit that strikes northwest and dips approximately $82^{\circ}$ to the east seems to intersect the CLH (Fig. 12). This fault, locally referred to as the Felix fault, appears to be a major flexure in the CLH and transforms it from N$\mathrm{S}$ to NW-SE. The Felix fault most probably, is the same structural feature that manifests itself as a lineament that can be traced across much of the Sefwi-Bibiani volcanic belt. 


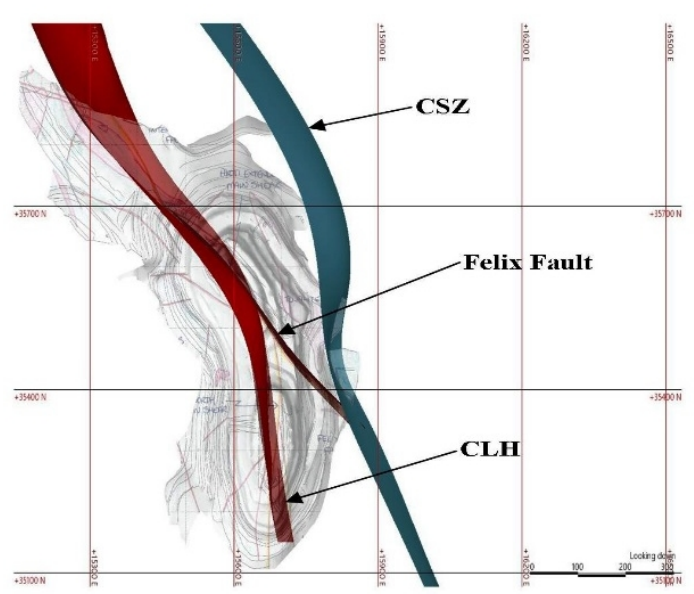

Fig. 11 Aerial View of Akoti North-Akoti Extended Deposit showing the Kinks in CZS and CLH

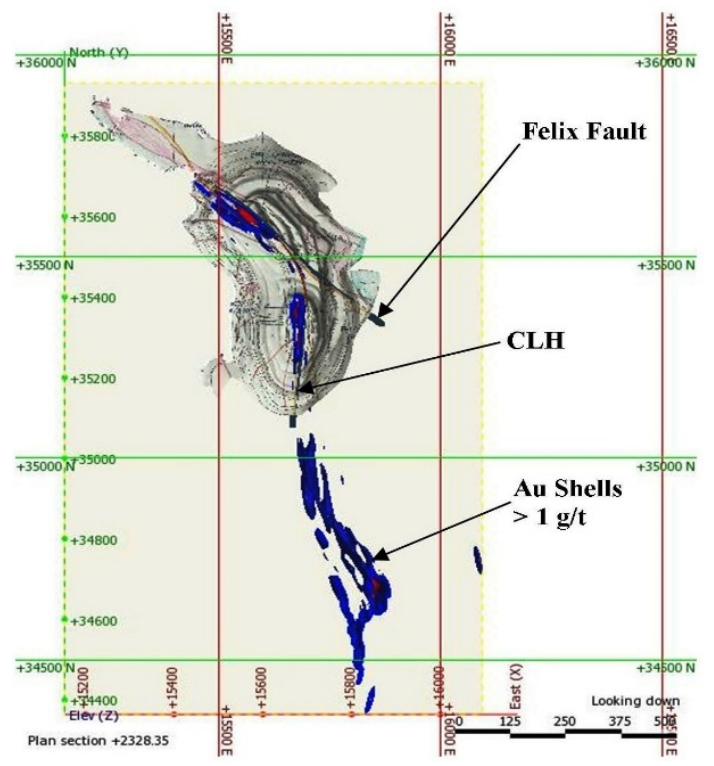

Fig. 12 Plan Section of Akoti Fault showing Felix Fault and the CLH at Akoti Deposit

The CLH is locally referred to as the Akoti fault within the Akoti North-Akoti Extended deposit. The Akoti fault zone exhibits a brittle-ductile fabric of about $50 \mathrm{~cm}$ in width and intimately associated with the zone is a smoky grey quartz vein that acts as a marker to the fault.

\subsubsection{Akwaaba Deposit}

The CLH and the CSZ merge at Akwaaba. CLH has a strike of $015^{\circ}$ and dip of about $78^{\circ} \mathrm{W}$. It forms the contact between the Birimian metavolcanics and the younger Tarkwaian sedimentary rocks (Figs. 13 and 14).

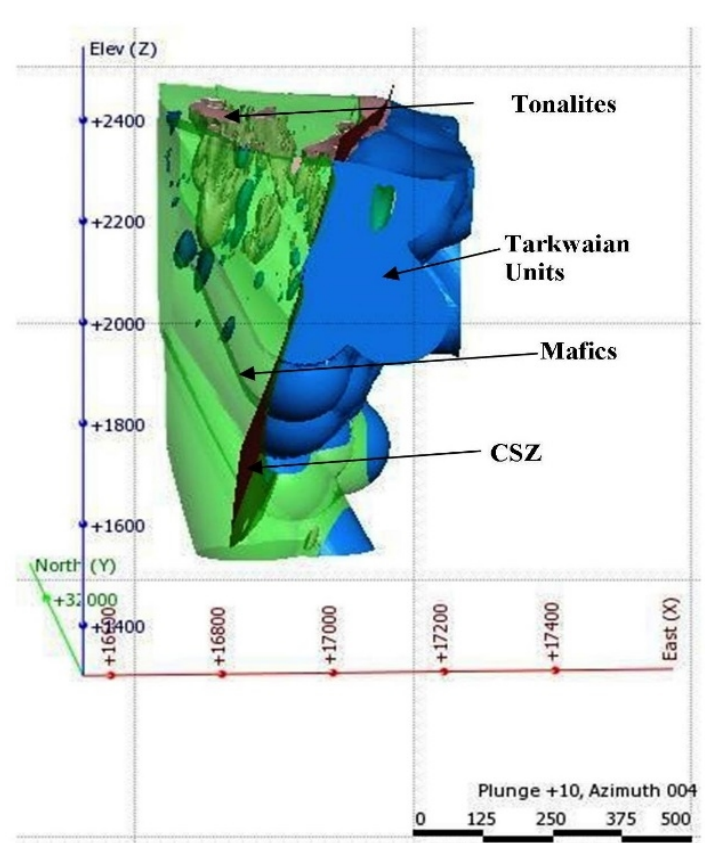

Fig. 13 Leapfrog Model of Akwaaba Deposit illustrating Geology and Shear

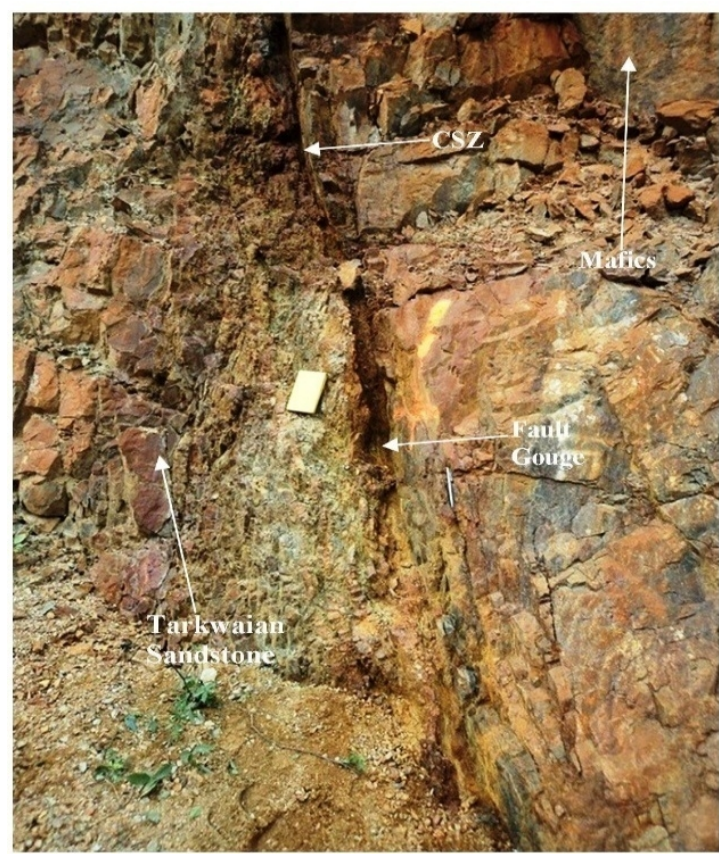

Fig. 14 An Image of the Chirano Shear in Akwaaba Pit (Looking South)

The CSZ is seen as a grey fault gouge of about 20$40 \mathrm{~cm}$ thick and bounds mineralisation on the east. The ore zone is $30-50 \mathrm{~m}$ wide and is characterised by ductile-brittle to ductile deformation comprising foliation, shearing and brecciation, cataclasis and veining (Fig. 15). The intensity of both foliation and brecciation increases remarkably within $10 \mathrm{~m}$ of the CSZ. 
There is a distinct brecciated fabric of the CLH that consists of quartz vein fragments with abundant pyrite and traces of graphite locally referred to as black breccia. This unit contains high gold grades of up to $28 \mathrm{~g} / \mathrm{t}$.

Stereographic plots of foliations derived from some drill core measurements from Akwaaba indicate a peak density of $82{ }^{\circ} \mathrm{W}$ dip. Foliation intensity and cataclasis decrease drastically in poorly mineralised areas.

Striations and slickensides on the surface of the western and eastern walls of the Akwaaba pit suggest the west block moved to the south relative to the east block.

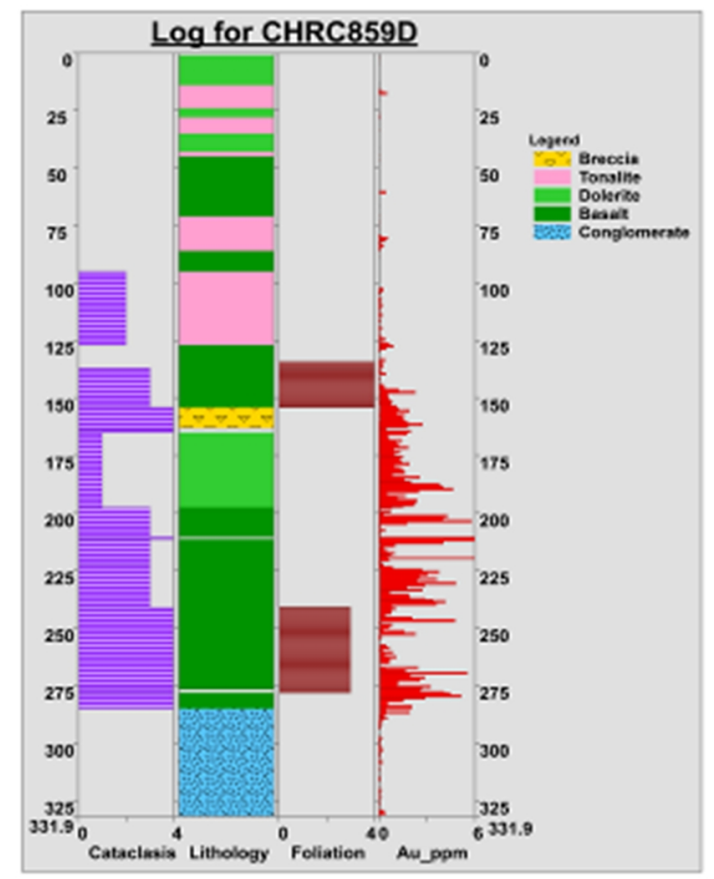

Fig. 15 Graphic Log of Drill Core showing Structural Matrix at Akwaaba

\subsection{Discussion}

Deposit and district scale analyses confirm that all the Chirano deposits lie along a single structural corridor that is hosted within a secondary fault or shear zone system known as the CSZ. The CSZ is associated with the major Bibiani Shear on a regional scale (Anon., 2009). On the scale of individual deposits, the morphology of the CSZ and its associated splays may be grouped into three major categories namely: (1) laminated veins in shear zones (2) breccias (3) ductile to brittle-ductile zones. The various geometries are a function of the rheological contrast of the host rocks and are probably the result of temperature and pressure at which deformation took place.

The Sariehu deposit has morphology of laminated veins in shear zone. The sheeted veins are coarsegrained and may have developed during a rapid veining event that took advantage of pre-existing and steeply dipping foliation fabric in the mafic units. They are closely spaced where they are in close proximity to the CLH. However, the spacing increases the further they are from the CLH. Vein thickness generally decreases as the distance from the CLH increases. The veins formed in the hanging wall have remarkable sub-vertical dips that suggest they are extension veins.

The Akwaaba, Akoti North-Akoti Extended, Paboase and Obra deposits are similar in morphology of breccia and ductile to brittle-ductile geometries. These include penetrative foliated domains of shearing, foliated and non-foliated zones of brecciation, fracture sets and veins. The shear zone architecture of the Chirano deposits suggests different phases of movement along the CSZ and its related splay. This view is confirmed by Allibone et al. (2004) who indicated that there are at least 3 phases of movement on the CLH. Gold mineralisation in most of these deposits seems to have been centered in a complex system of ductile to brittle-ductile structures of breccia, foliated brecciated fabrics and stockwork of veins. Brecciation and foliation have overprinted within the shear architecture of the CSZ and its related CLH. Some breccia units contain foliated rock fragments which seem to suggest that brittle deformation of brecciation occurred after a major shearing event.

Though the CLH seems to be a continuous structure, it has a sinuous geometry with subtle changes in its orientation that are deposit dependent (Fig. 16). These changes in orientation range from N-S, NE-SW, NW-SE and NNW-SSE.

Leapfrog model of gold grades in the various deposits suggest that the structure is associated with bends, bifurcations and smaller splays that may have developed adjacent to the main shear structure.

There is direct correlation between the geometry of the shear zone and grade distribution. High gold grades seem to be centered in areas of brittleductile domains of shearing and brecciation. Graphic log plots of some drill holes show that gold mineralisation increases in areas where the intensity of cataclasis is more pronounced than in zones where foliation intensity is high. This suggests that high gold grades are in highly brecciated zones. 


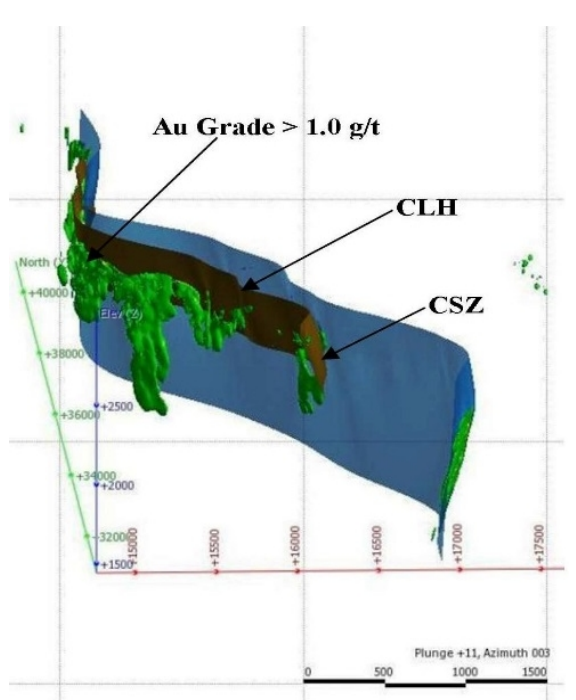

Fig. 16 A 3-D Model of Chirano Structures and Gold Grade on a District Scale

The mineralised zone within the CLH is intimately associated with hydrothermal alteration of albite, silica, ankerite, sericite, pyrite and graphite assemblages. Alterations in the mineralised zones tend to be influenced by host rock compositions.

The alteration assemblage within the CSZ seems to have remarkable signature to Induced Polarization geophysical method. This may be the result of high silica intensity and albitization associated with the CSZ.

Faults within the CSZ system seem to have undergone various movements over a period of time. There is evidence to suggest a sinistral sense of movement at the Tano pit and also dip-slip movement recorded in one drill hole. Dip-slip reverse movement may have occurred at one stage probably before the sinistral strike-slip movement occurred as observed on the shear surfaces at Tano and Akwaaba pits. The strike-slip sinistral movement may have reactivated the CSZ.

The Felix fault which probably is the lineament that is traced in much of the Sefwi-Bibiani volcanic belt most probably is a NW-SE transfer fault that cuts or links the third phase of deformation (D iii) in the district from the Birimian meta-sedimentary Basin.

The geology model of the Akwaaba deposit seems to suggest that the younger Tarkwaian sediments thrust unto the mafic units after movement or reactivation of the CSZ. The model shows that beneath the Tarkwaian is another mafic package. The 'conglomerate' feature seen proximal to the CSZ may be a good marker for exploration targeting. These units can be seen in most of the deposits.

\section{Conclusions}

From the foregoing, the following conclusions are drawn:

The gold deposits of the Chirano mine are located along a continuous structural corridor known as the CSZ. This structural corridor is characterised by splays, foliated shear zones, laminated, sheeted and sheared veins, cataclasites and hydrothermal alterations. The morphology of the Chirano structural architecture may be categorised as:

(a) Laminated veins in shears;

(b) Breccias; and

(c) Ductile to brittle-ductile zones.

The CSZ has different orientations in dip and strike from the south of the mining lease to the north. The subtle changes in orientation are deposit dependent and seem to alternate from N-S to NE-SW, NNWSSE and NW-SE. The structure has a sinuous shape and tends to pinch and swell.

Gold mineralisation is centered along the structural corridor and this gives a very strong correlation between the shear geometry and mineralisation. Exploration efforts may target shear geometry as key to finding more mineralisation at depth.

The Chirano mining lease area has undergone prolonged structural deformation especially along the CSZ corridor. Strike-slip sinistral sense of movement most likely was one of the events that took place syn-mineralisation. Another event that took place probably around the same time is the faulting from the Birimian Basin through the Chirano shear. This is most probably the Felix fault which fits the (D iv) deformation.

\section{Acknowledgements}

This work was funded by Chirano Gold Mines Limited and we acknowledge the support given us by the management of the Exploration Department and also the permission to publish this material. Immerse appreciation also goes to the Chirano exploration team for their various contributions towards a successful completion of the work.

\section{References}

Allibone A., Teasdale J., Cameron G., Etheridge M., Uttley P., Soboh A., Appiah-Kubi J., Adanu A., Arthur R., Mamphey J., Odoom B., Zuta J., Tsikata A., Pataye F. and Famiyeh, S. (2002), "Timing and Structural Controls on Gold Mineralization at the Bogoso Gold Mine, Ghana, West Africa”, Economic Geology 97, pp. 949-969.

Allibone A., Hayden P., Cameron G. and Duku, F. (2004), "Paleoproterozoic Gold Deposits 
Hosted by Albite- and Carbonate-Altered Tonalite in the Chirano District, Ghana, West Africa", Economic Geology 99, pp. 479-497.

Anon. (2008), "Chirano Gold Mine Geological Report”, Technical Report REB001/08, pp. 510.

Anon. (2009), "Chirano Gold Mine Technical Report”, Technical Report No. 05/09, pp. 8-10.

Barritt, S. D. and Kuma, J. S. (1998), "Constrained Gravity Models and Structural Evolution of the Ashanti Belt, Southwest Ghana, Journal of African Earth Sciences, Vol. 26, No. 4, pp. 539550.

Condie, K. C. (1989), “Archean Crustal Evolution", Elsevier, Amsterdam, 86 pp.

Davis, D. W., Hirdes, W., Schaltegger, E.and Nunoo, E. A., (1994), "U/Pb age constraints on deposition and provenance of Birimian and gold-bearing Tarkwaian sediments in Ghana,West Africa", Precambrian Reserch, vol. 67, pp. 89-107.

Dzigbodi-Adjimah, K. and Asamoah, D. N. (2004), "The Geology of the Gold Deposits of Prestea Gold Belt of Ghana", 90th Anniv. Conference, Ghana Geological Survey, pp. 3-15.

Eisenlohr, B. N. (1992), "Conflicting evidence on the timing of mesothermal and paleoplacer gold mineralisation in early Proterozoic rocks from southwest Ghana,West Africa", Mineral Deposita, Vol. 27, pp. 23-29.

Eisenlohr, B. .N. and Hirdes, W. (1992), The structural development of the early Proterozoic Birimian and Tarkwaian rocks of southwest Ghana, West Africa. J. Afr. Earth Sci., 14, pp. 313-325.

Kesse, G. O. (1985), The Mineral and Rock Resources of Ghana, A.A. Balkema, Rotterdam, $610 \mathrm{pp}$.

Ledru, P., Milesi, J. P., Vinchon, C., Johan, V., Marcoux, E. and Ankrah, P. (1988), "Géologie et gitologie de l'or des series birrimiennes du Ghana”, BRGM report, 88AFO 122 GEO., 36 pp.

Leube, A., Hirdes, W., Mauer, R. and Kesse, G.O. (1990), "The Early Proterozoic Birimian Supergroup of Ghana and some aspects of its associated gold mineralisation”, Precambrian Research, Vol. 46, pp. 139-165.

Milesi, J. P., Ledru, P., Feybesse, J- L., Dommanget, A., Marcoux, E., Prost, A., Vinchon, C., Sylvain, J. P., Johan, V., Tegyey, M., Calvez, J. Y. and Lagny, P. H. (1989), "West African Gold Deposits in their lower Proteroic Lithostructural Setting”, Chronologique Researchezs Minieres 497, Editions of BRGM, Orleans, France, 96 pp.

Milesi, J. P., Ledru, P., Vinchon, C. and Marcoux, E. (1991), "The metallogeneetic relation between Birimian and Tarkwaian gold deposits in Ghana",Mineral Deposita, Vol. 26; pp. 228238.
Pigois, J. P., Groves D. I., Fletcher, I. R., McNaughton N. J. and Snee L. (2003), "Age constraints on Tarkwaian paleoplacer and lodegold formation in the Tarkwa-Damang district, SW Ghana", Mineralium Deposita 38 pp. 695714.

Woolford, A. (2007), "Akwaaba Geological Report", Unpublished Technical Report, pp. 1012.

\section{Authors}

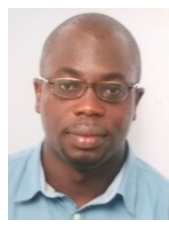

Kwamina Ackun-Wood is a Senior Geologist at Chirano Gold Mines Limited, a Kinross Company. He holds degree in MSc in Geological Engineering. His research and professional works include structural and geological analysis, geostatistics and resource modelling.

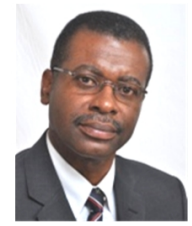

Professor Jerry S. Y. Kuma is a Professor of Environmental Hydrogeology and Geophysics at the University of Mines and Technology (UMaT), Tarkwa. He holds a BSc (Hons) in Geology and Physics from the University of Ghana; PG Dip and MSc (with distinction) degrees in Geophysics from Delft, The Netherlands; and $\mathrm{PhD}$ in Water Resources Engineering from the Civil Engineering Department from the University of Newcastle upon Tyne, England. He is actively involved in the Hydrology of mining districts and other Water Management issues in Ghana. He is a member of the Ghana Institution of Geoscientists (GhIG), Ghana Institution of Engineers (GhIE) and the International Association of Hydrogeologists (IAH). He is also a fellow of the African Scientific Institute (ASI)

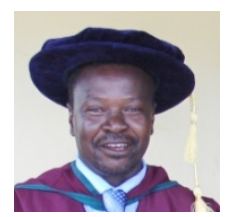

Dr J. A. Yendaw is a Lecturer in Geotechnical Engineering at the University of Mines and Technology (UMaT), Tarkwa. He holds Diploma and BSc (Hons) in Geological Engineering from the Kwame Nkrumah University of Science and Technology (KNUST); and $\mathrm{PhD}$ in Geotechnical Engineering from the Heriot-Watt University, Edinburgh, UK. Dr Yendaw has vast experience in geological mapping in exploration for gold deposits and geotechnical engineering. His research interests are in Rock Mechanics and Foundation Engineering. $\mathrm{He}$ is a member of the Ghana Institution of Geoscientists (GHIG). 